\title{
The Ambiguity that Surrounds Information Strategy
}

\author{
Karl T. Knox \\ Nottingham Trent University, Department of Management, \\ Nottingham, United Kingdom
}

\author{
karl.knox@ntu.ac.uk
}

\begin{abstract}
The notion of an information strategy is one that is pervasive in many areas of business and organisations. Specifically, the area of higher education has been a focus of this research given its historical involvement with information strategy formulation (Joint-Information-SystemsCommittee 1998a, 1998b, 2004). The underlining premise, of an information strategy, is as a mechanism for managing information. Given that information is an important part of business and organisational operations (Dhillon 2001; Earl 2000), Stahl (2006, p.83) argues "more and better information is often seen as prerequisite for better management practices"; the notion of managing information through an information strategy seems a logical step. Unfortunately the reality and the theory are somewhat mismatched.

This paper discusses the notion of information strategy from three distinct perspectives that of Information Systems (IS), Library and Information Science (LIS), and a term that the author refers to as General Management (GM) which focusses upon the theoretical underpinnings. Whereas, highlighting findings from the research suggests the reality of what organisations are actually doing in relation to the formulation of an information strategy. The aim is to highlight both the pervasive use of an information strategy as well as the ambiguity that surrounds its use.

The contribution of the paper highlights and extends the debate as to why different interpretations of information subsequently impact on the information strategy formulation process. Indicating that, upon reflection, there is no right or wrong definition only ambiguity surrounding its use and formulation. The formulation of an information strategy is not value/subjective-free or straight forward. It is one that requires thought, discussion and understanding if it is to be successful.
\end{abstract}

Keywords: information, information strategy, information systems, library and information science and general management

Material published as part of this publication, either on-line or in print, is copyrighted by the Informing Science Institute. Permission to make digital or paper copy of part or all of these works for personal or classroom use is granted without fee provided that the copies are not made or distributed for profit or commercial advantage AND that copies 1) bear this notice in full and 2) give the full citation on the first page. It is permissible to abstract these works so long as credit is given. To copy in all other cases or to republish or to post on a server or to redistribute to lists requires specific permission and payment of a fee. Contact Publisher@InformingScience.org to request redistribution permission.

\section{Introduction}

Irrespective of organisation, discipline, or sector the notion of information has and will continue to have a huge influence over activities, operations, and strategy. The role and use of information emerges from the 'need' of organisations to understand their customers and processes better. The inference, 
from much of the literature, suggests that organisations will achieve competitive advantage and therefore differentiate themselves from their competitors. The result of this approach encourages organisations focus upon the collection, collation, analysis, interpretation, and distribution of information to all areas of the organisation. The mechanism that has been used to support this process has been through the use (and abuse) of technology. Technology allows the management of huge amounts of information at a fraction of the time and cost that has been attributed to this process historically.

In conjunction with the above internally focussed approach to information, there has also been an external view. That is, organisations operate within what has been termed the information economy (Peppers \& Rogers, 2011) or the information society, where Beynon-Davies (2009, p. 3) argues that "the way in which information is increasingly regarded as an important economic 'commodity'" has influenced organisational actions. This external influence expands to terms such as the information age or even the knowledge society, all of which align and encourage a focus upon and relationship with information as a strategic activity within businesses and organisations (Athique, 2013; Belanger \& Van Slyke, 2012; Drucker, 1969; Duff, 2002).

This focus and involvement with information continues to-date, for many of the reasons raised previously, even though the discussion and debate that surrounds information within organisations has been prevalent for the past 50 years, for example, Ackoff (1967) identifies that the term information is simply misleading, Wilson (1986, p.12) states that "when we look more closely at the nature of information, that everyday certainty about its character disappears," Boland (1987, p. 377) argues that "information is not a resource to be stockpiled as one more factor of production," and Davenport (Davenport, 1997; Davenport, Eccles, \& Prusak, 1992) argues that gaining agreement within organisations in regards to terms and definitions is problematic.

The importance placed upon organisations to manage their information and subsequently their knowledge has been cited as a major factor in organisations achieving success (Drucker, 2002; Harris, 1993). This relationship between information and organisational success, the author would argue, has been the tenuous link many organisations have used as the impetus to formulate an information strategy. It is suggested that organisations have misjudged, misinterpreted, and misaligned the notion of an information strategy and as such implies why the ambiguous nature of an information strategy pervades (Knox, 2009; Mutch, 2008; Neyland \& Surridge, 2002; Pearlson \& Saunders, 2013).

The view that there are multiple interpretations and definitions of a commonly used term, 'information' (Knox 2009), based on various factors all of which are valid, from the individual perspective, infers that formulating an information strategy as a mechanism for managing information becomes problematical, ambiguous, and leads the author to the view that an information strategy becomes one of either:

- Placation - where the strategy is 'seen to be written', as opposed to

- Implementation - where the strategy is 'written to be seen'

It is within the field of higher education that the author can infer that to-date the majority of information strategies identified fall into the former as opposed to the latter. That is, strategies that were identified as information strategies were in fact misjudged and misaligned with other traditional strategies found within the organisational context, i.e., information technology strategies.

It is hoped that by the end of the paper the reader will have an appreciation of both the fundamental issues of defining the term information from a discipline perspective and how this then impacts on the formulation of an information strategy. The recognition that an individual's understanding, discipline alignment and experience will impact on how an information strategy is for- 
mulated within an organisation is a fundamental step in appreciating why, to-date, the notion of an information strategy is both ambiguous and contentious.

\section{Information Strategy and Informing Science}

Within the informing science framework (Figure 1.) there is an affinity with the notion of information, discussed previously in Knox, 2009. A brief overview of that discussion is provided in Table 1.

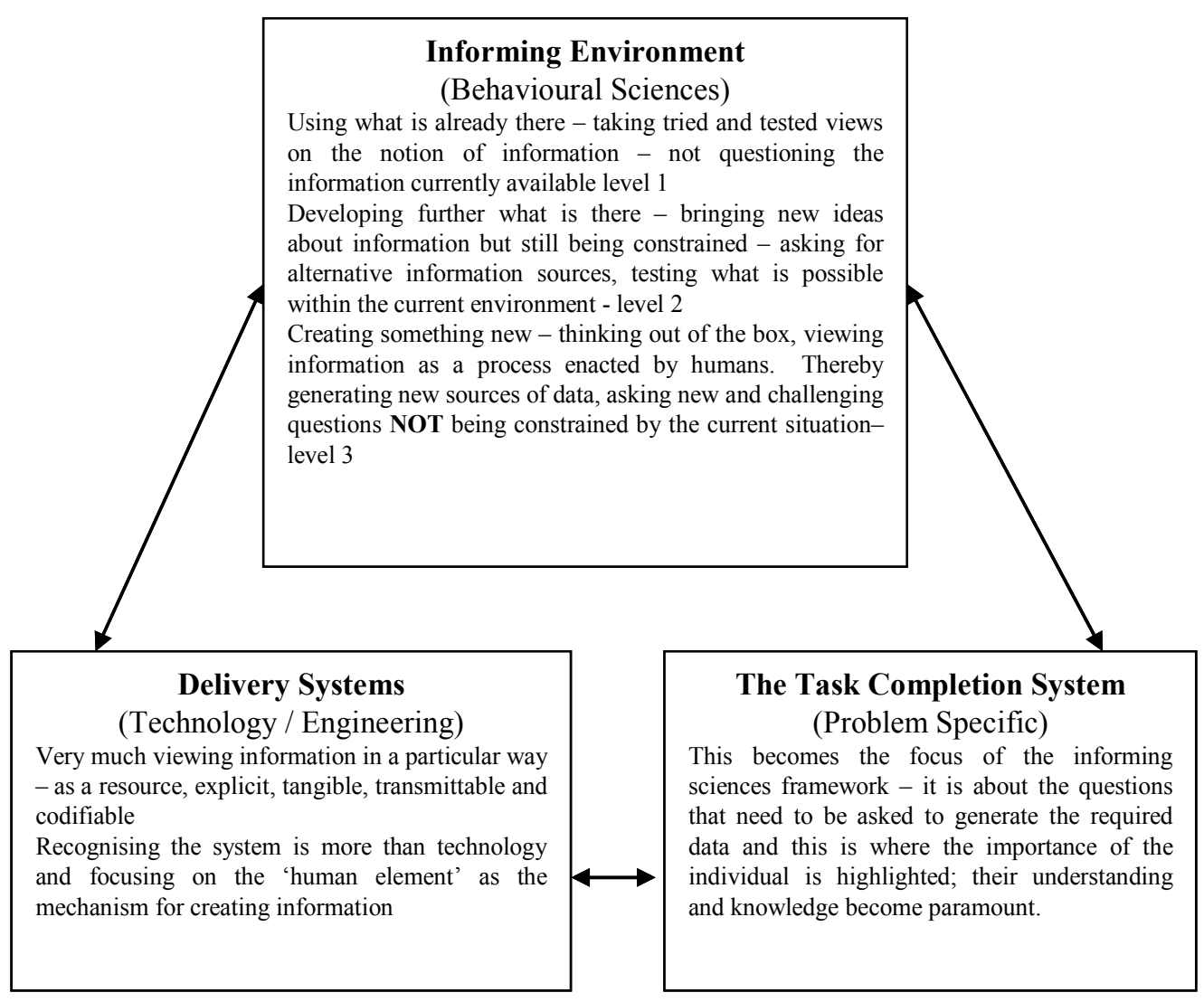

Figure 1. The Informing Science Framework in relation to 'information' (Knox, 2009)

If, as suggested, information is a cornerstone of the informing science discipline then the corollary is that the notion of an information strategy is also relevant. Discussing and understanding the role of an information strategy, in terms of the informing science framework, seems a good starting point. What the author has done is to use the three lens approach (information systems, library and information science and general management) to identify how different perspectives can be seen to influence understanding of an information strategy in line with informing science.

\section{Informing Environment}

The three levels within the informing environment infer an 'overarching' view of an information strategy as a mechanism to assist in managing information at a basic level within the organisation, at the next level in providing access and support, and finally at the next level of creating new designs for informing. This may be a starting point for redefining how things or approaches are undertaken, and the information strategy is a strategy that may assist in that approach. 


\section{Delivery Systems}

The author has equated the informing sciences framework delivery systems with the lens of information systems. That is, the delivery system refers to the mechanism by which information is transferred. The view taken is one of information being seen as a resource that is managed by technology. This then infers that the role of an information strategy is one of managing technology that in turn manages information. As the name information strategy suggests information is contained, within the network, the architecture, and the physical resources; information is seen as a resource that is there to be managed. The assumption is that when formulating an information strategy the focus will be on technology and technological related issues. This is the view that is found within the information systems discipline (as discussed later in the paper) and is then assumed it may be viewed in this way by the delivery systems aspect of the informing science framework.

\section{The Task Completion System}

The task completion system focuses upon the management lens, where it is about emphasis on the tasks that need completing. That is the notion of moving forward, understanding what needs to be done within the organisation, and what needs to be accomplished. Understanding and managing information to assist in that process, from a management perspective, generates a strategy to accomplish that task. The management view indicates the formulation of an information strategy will assist in understanding and managing information both internally and externally.

The use of the informing science framework has highlighted different approaches and possible ambiguities that could arise within a discipline framework approach. It signifies that formulating an information strategy may require more thought as each part of the framework identifies different interpretations of information and therefore an information strategy. The information strategy could also be taken as an 'overarching' approach that would encompass all aspects of the informing science framework and again this is an area for further discussion. The following paragraphs focus on one 'lens' that of the information systems discipline and its approach to information strategy formulation.

\section{Information}

\section{Information Systems (IS)}

To provide a precise definition of information, from the information systems (IS) literature, that everyone agrees upon seems to be somewhat difficult. Information is non-visible; Pearlson and Saunders (2013, p. 17) state "information is in the ether," it is created by individuals through their understanding and interpretation of data, therefore intangible. The author would argue that 'information' is a human centred activity or attribute and not one that technology currently mimics. So in line with Boland's (1987) argument information cannot be stockpiled, it is not 'out there' waiting to be found and can mean different things to different people.

A common approach to information, found within the information systems (IS) literature, implies that it is often equated or assimilated with that of data and placed in a traditional data, information, and knowledge hierarchy (Chaffey \& White, 2011; Pearlson \& Saunders, 2010). The method of identifying differences is based upon the attribution of meaning. The literature fails to clarify 'what' or 'whom' bestows that meaning indicating that seems to be an agreed and accepted form of explanation.

Within the information systems (IS) discipline the implication is that data is transformed through the use of technology to produce information. Technology has provided the means with which to 
manage huge amounts of data and to provide levels of granularity and pattern attribution that were previously incomprehensible to business managers. The association and reliance upon technology has created the immutable bond between information and technology (Davenport 2000).

\section{Library and Information Science}

Other disciplines also have an affinity with information. Within library and information science (LIS) the interdisciplinary nature of the discipline incorporates the notion of information and can be seen through the practises of searching, collating, organising, preserving, and disseminating of material. The discipline also includes the processes of managing access and interaction with the stated resources, indicating that the management of information has a central focus. What resonates within the discipline is that the library has been seen as a learning resource and individuals who manage that resource are custodians and guardians of both information and knowledge.

Where library and information sciences (LIS) differs from the information systems (IS) is in their approach to information in that LIS does not necessarily equate information and/or an information strategy with technology or systems but focusses upon information in terms of the access to knowledge and information products. That is, the management of information in the form of physical products, i.e., books, journals, and now more importantly electronic resources. The Library Association $(1996, \mathrm{p} .1)$ infers "that in many cases the management of information appears to be evolving somewhat haphazardly." The discipline does not necessarily define information but acknowledges it as "what humans transform knowledge into when they want to communicate to other people" and adds to the view of information by stating that [information] "is knowledge that is made visible or audible, in written or printed words or speech" (Orna 1999, p. 8). This implies that, within the library and information sciences (LIS) discipline, information has a tangible format and that their role manages that resource in the capacity as information specialists.

\section{General Management}

This concept that information can be seen as a mechanism for communicating meaning has been identified within the general management discipline, where Marchand (1997) argues that "information allows you to express, transfer and convey knowledge." The domain of general management is a term that is used to encapsulate those individuals whose role involves 'managing' within an organisational setting. In terms of general management it can be argued that irrespective of the size of the organisation or whether they are in the public or private domain the role of management and managing organisations is experiencing profound changes. Changes are occurring in operations, resources, markets, and technology so there is a need for organisations to better understand their internal and external activities and adjust to meet the needs of these changes. In some cases the very modus operandi that organisations have followed is being brought into question, requiring management to fundamentally change how they operate. Viewing information as a mechanism that assists in that change is a theme found within much of the management literature, from gaining competitive advantage (Porter \& Millar 1985) to all businesses being information businesses (Earl, 2000). In fact, Chaffey and White (2011, preface) identify "that the volume of information that organisations need to manage continues to increase relentlessly." The view taken within the general management (GM) discipline, in terms of information, seems to be one where information is viewed as a mechanism to control and monitor the whole operation in minute detail. This view is seen by Cole and Kelly's (2011, p. 338) statement that "the goal of today's organisation is having the right information, in the right, place, in the right format, at the right time - at the right cost."

There seems to be, across all the three disciplines of information systems (IS), library and information science (LIS) and general management (GM), a multitude of avenues one could follow in 
relation to the notion of information and an information strategy, these are summarised in Table 1.

Table 1: An overview of discipline approaches to information and information strategy

\begin{tabular}{|c|c|c|}
\hline Information Systems & $\begin{array}{c}\text { Library and } \\
\text { Information Science }\end{array}$ & General Management \\
\hline $\begin{array}{l}\text { Data, information and knowl- } \\
\text { edge and the relevance and } \\
\text { role of technology in provid- } \\
\text { ing access, support, and man- } \\
\text { agement of these } \\
\text { needs/resources is the focus. } \\
\text { Interchanging terms used and } \\
\text { a view that information is tan- } \\
\text { gible and manageable via } \\
\text { technology } \\
\text { An information strategy man- } \\
\text { ages that resource of informa- } \\
\text { tion } \\
\text { An elected affinity between } \\
\text { technology and an information } \\
\text { strategy }\end{array}$ & $\begin{array}{l}\text { Managing and maintaining } \\
\text { access, providing value for } \\
\text { money and a variety of re- } \\
\text { sources that meet the needs of } \\
\text { users across the organisation. } \\
\text { A focus on policy, document } \\
\text { management, compliance ini- } \\
\text { tiatives and best practice stan- } \\
\text { dards } \\
\text { An information strategy is } \\
\text { aimed at managing tangible } \\
\text { resources. } \\
\text { An information strategy is } \\
\text { 'nested' within information } \\
\text { policy }\end{array}$ & $\begin{array}{l}\text { Internal, external, order and } \\
\text { flexibility approaches to in- } \\
\text { formation with the notion of } \\
\text { strategic alignment between } \\
\text { information systems, informa- } \\
\text { tion technology and business } \\
\text { needs as a mechanism for } \\
\text { managing information } \\
\text { There is a focus on managing } \\
\text { information assets - a resource } \\
\text { based view - as a mechanism } \\
\text { to ensure all resources are } \\
\text { used to their fullest both inter- } \\
\text { nally and externally } \\
\text { Information is seen as 'power' } \\
\text { and managing that asset is a } \\
\text { way of attaining competitive } \\
\text { advantage. }\end{array}$ \\
\hline
\end{tabular}

In light of the three discipline outlined in Table 1, it is noted that, at this stage, the author will focus upon the discipline of information systems as an initial mechanism to discuss the notion and ambiguity of an information strategy. Coupled with this focus is the placement of an information strategy within the realms of higher education (HE) due to HEs past focus on information strategy formulation(Joint-Funding-Councils-Libraries-Review-Group [JFCL], 1993; JointInformation-Systems-Committee [JICS], 1995a, 1995b).

\section{Information Systems Discipline}

The notion of an information strategy is not necessarily new, given that during the 1990s many environments and specifically those within Higher Education (HE) pursued the formulation of information strategies with much vigour. This was as a result of both The Joint Funding Council's Libraries Review (JFCL, 1993) and the Joint Information Systems Committee (JISC) directives. Both parties had as their general raison d'être the improvement of information: JISC (1995b) via the accessibility of information through technological networks and management of information through information strategies; and the JFCL Report through the reassessment of the way that institutions, specifically libraries, plan and provide for the information needs of those working within them. Both advocated the formulation of an information strategy as a mechanism for managing information and both linked the formulation of an information strategy to funding, making organisations extremely receptive. 
Historically, much of what had been referred to as information strategy formulation had in fact been quite removed from the concept of 'information'. As far back as 1996 and again in 2003 Allen and Wilson argue that (1996, p.240) "there does not seem to be any consensus on basic issues, such as what an information strategy consists of, and little knowledge of how to go about developing an information strategy"; again Allen and Wilson (2003, p. 223) acknowledge that "there is, [still] little empirical research on the process of information strategy formulation." This creates a contentious nature regarding both what an information strategy is and how to formulate an information strategy. This contentious nature is also identified within the definitions offered throughout the discourse where many authors (Allen, 1995; Beynon-Davies, 2009; Boddy, Boonstra, \& Kennedy, 2002; Currie \& Galliers, 1999; Earl, 1989; Galliers, 1991; Macmillan, 1997; Pearlson, 2001; Wilson, 1989) have offered insights but have not defined what it means; often it is amalgamated with other strategies, processes, or plans. General issues identified by authors indicate that getting total agreement on concepts is a difficult process. There are also, within the IS domain, issues of terminology, levels of granularity, and positioning of strategies within the wider strategy formulation process; all of which make the notion of an information strategy difficult to formulate.

The definitions offered within the discourse are extremely disparate; early investigations identified an information strategy as being a sub-set of the information systems strategy (Allen \& Wilson, 1997), whereas others have highlighted the view that the information strategy is an overarching strategy, which uses information communication technologies (ICT) to assist the organisational strategy via information flows (Wilson 2001). There is also a suggestion that the information strategy's overall aim, for users of information, is an attempt to achieve that one true source, a central area that holds the correct data. This equates data and information together without offering any reasoning as to how one becomes the other. This diversity in definition was noted by Hall (1994, p. 282) where she acknowledges, when researching the Scottish Textile industry, "that there is much interest for information issues but that this interest is focussed on information technology as an enabling technology to share this information and that information as a strategic resource is not altogether appreciated."

When information strategy is identified, the focus is upon an array of related but very different strategies, e.g., an information technology strategy, an information systems strategy, an information management, an informatics strategy. Within the literature some specific acknowledgements of an information strategy incorporate the following: an alignment between an organisations' structure and the information system that supports its operations (Jordan \& Tricker 1995); information strategy in the NHS, which focuses on a national information technology strategy (Keen and Muris 1995); information strategies in UK higher education institutions, where the theme relates to the failure of IT-driven applications not fulfilling their promise (Allen \& Wilson, 1996); information strategies where the alignment of the business case highlights the need to manage informational assets (Asprey 2004); the development of an national information strategy in Scotland, where the emphasis is placed upon open access and institutional repositories (Law, MacGregor, McCulloch, \& Wallis 2005); an information strategy as a systems strategy, or other technically focussed issues (Goldschmitt, 2004); an informatics strategy as a mechanism for managing all things informational (Beynon-Davies, 2009, p. 283). All of the above identify a number of alternative foci with regards to the concept of an information strategy, all tending to focus on everything but what their title infers, that is, information.

Despite the level of ambiguity that has been identified, a number of authors have continued with their investigations into the notion of an information strategy. The following authors provide diagrammatical suggestions as to the relevance of an information strategy within a business context. 
Early work within the IS discipline focussed upon the planning, which provided a structure to follow (Earl, 1989). This and similar approaches, such as Galliers (1991), became the basis of subsequent investigations into information strategy formulation. Allen and Wilson (1996, p. 247) promote the view that the information strategy "acts as a linchpin between academic strategy or goals and the IS strategy", as seen in Figure 2. They argue that the information strategy brings "together the managed information resources to which the organisation has access and the available information technology resources" where it is seen to complete the circle between the information technology, information management, and organisational strategy, enabling the organisation to deliver information and information services organisation wide. However, Figure 2 clearly shows the information strategy as being a sub-set of the information systems strategy. Their focus is on the information systems strategy and not on information strategies per se. Acknowledging that viewing an information systems strategy as a holistic group of elements, as in Galliers' (1991) socio-technical approach, has not necessarily been wide spread; instead it has been tackled via a process of individual strategy formulation.

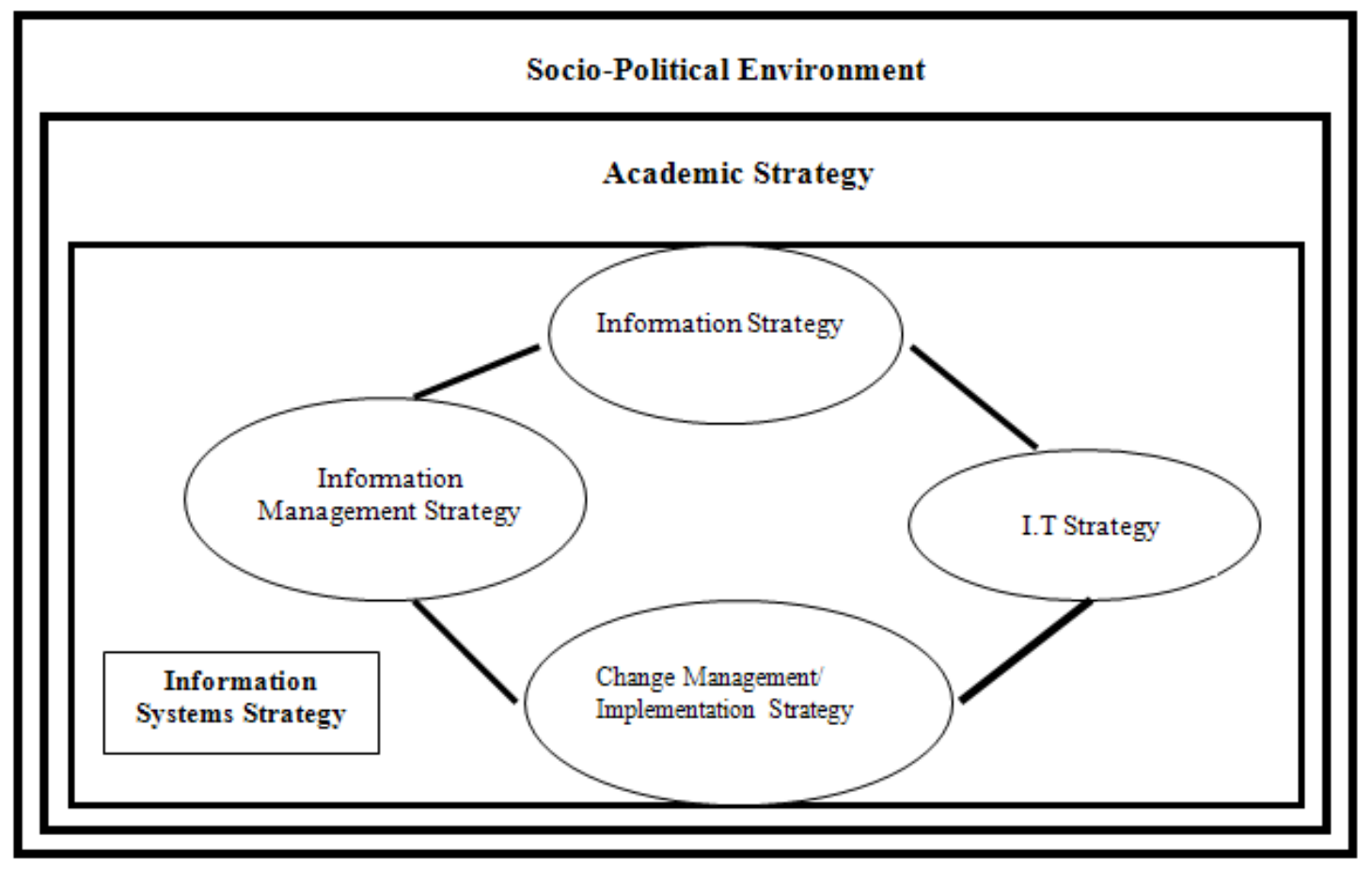

Figure 2: Information Strategy, The Linchpin Interpretation

Sources: Allen (1995, p. 4) - Components of an Information Systems Strategy;

Allen \& Wilson; 1996, p. 247. - Elements of an Information Systems Strategy - after Galliers; (1993)

Allen (1995) suggests that within the field of higher education most information strategy development tends to take a narrow view of what it is and what it consists of, arguing that "information strategy issues in higher education institutions tends to take a functionalist, mechanistic, deterministic approach focusing on the I.T. aspect almost to the exclusion of all other" (Allen \& Wilson, 1996, p.12).

Earl (2000) provides a developed view of an information strategy where he introduces the information resource strategy as part of an information strategy framework, seen in Figure 2. Earl's initial foray (Earl, 1988, 1989) into information strategy brought together three strategic elements: the information technology strategy, the information systems strategy, and the information management strategy. This was IS function oriented and said little about information strategy or 
the wider implication of these strategies to other organisational strategies. Earl's perspective, Figure 3, indicates that the information systems strategy is part of the information strategy framework. Earl uses a blended approach to information strategy where all of the strategies in Figure 3 are what make up the information strategy, making the information strategy the overarching strategy within which other strategies nest.

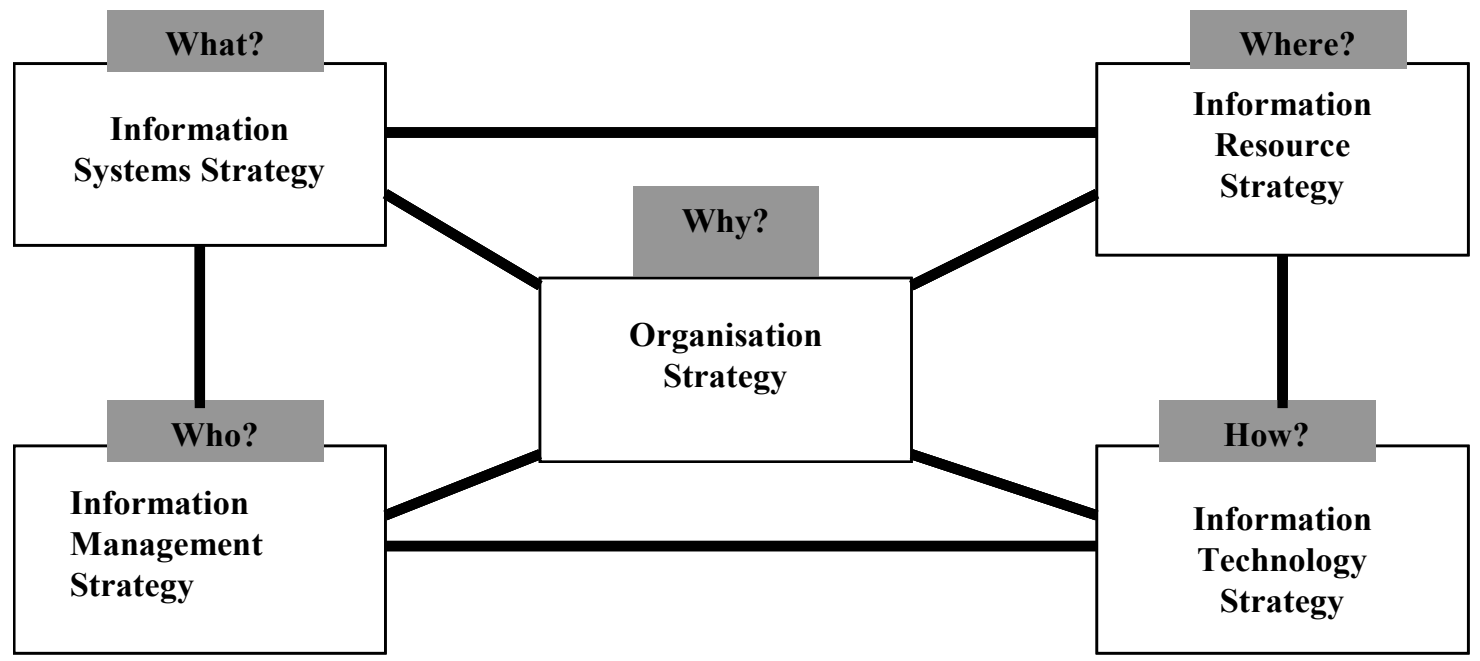

Figure 3: Earl's Information Strategy Framework (Source: Earl, 2000, p. 21)

Earl's argument for introducing the information resource strategy is acknowledged below:

[previous models did not recognise information] "now we can see that a fifth domain was missing - one that we still find difficult to formalise but in which companies increasingly have objectives, principles and policies. This is the domain of information as a resource, or of information resource strategy." (Earl 2000, p. 20)

This continuation of alternative perspectives, appears with Wilson (1998) who argues that an information strategy is an overarching strategy that defines how the organisation strategy interacts through information flows, with the aid of modern information and communication technologies, as seen in Figure 4. This indicates a number of different 'information' related strategies come together, feed into one another and through information and communication technologies culminate into an information strategy.
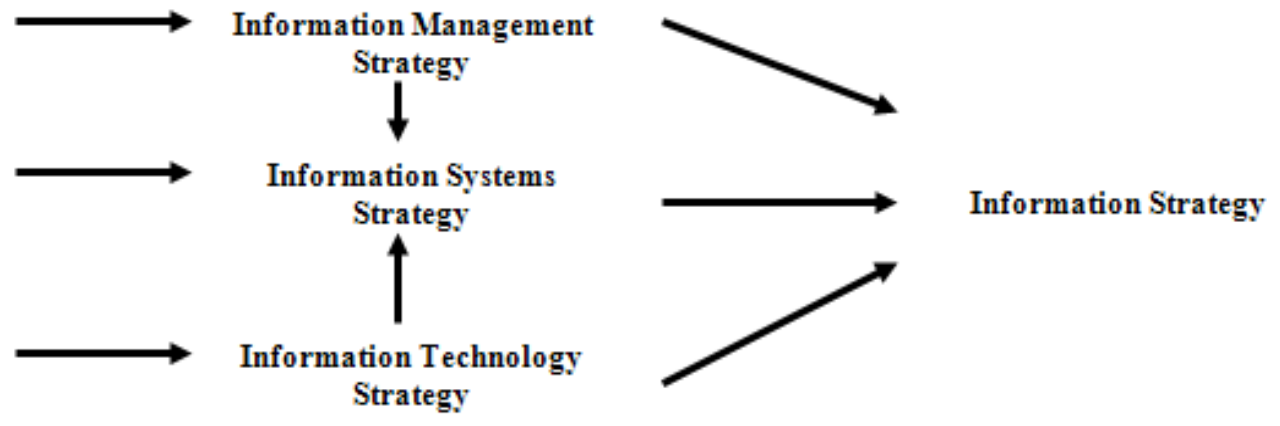

Figure 4: Wilson's information strategy (Source: personal communication with Tom Wilson)

The inference here is that everything flows through the preceding strategies and 'ends-up' as the information strategy. The use and interpretation of the IT, IS, \& IM strategies are in-line with 
Earl but infer that the IT \& IM strategies feed into the IS strategy as well as all contributing towards the information strategy, with no direct link to the overall organisational strategy as found with Earl's view. This linkage between information based strategies and business strategy is evident where Pearlson and Saunders (2013) acknowledge an information systems strategy triangle. Contained within that triangle is a reference to an information strategy, as seen in Figure 5.

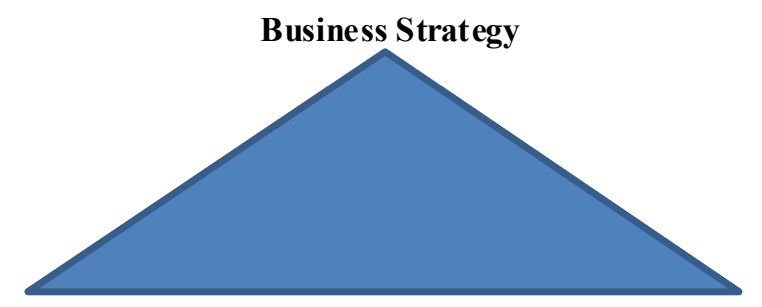

Organisational Strategy

Informatio n Strategy

Figure 5: Pearlson \& Saunders information systems strategy triangle.

Source: (Pearlson, 2001 \& Pearlson \& Saunders, 2013, p. 24)

The argument proposed by Pearlson and Saunders (2013, p. 24) is that "business strategy drives both the organisational strategy and the IS strategy... and successful firms carefully balance these three strategies [in that, they] purposely design their organisational and their IS strategies to complement their business strategy". The inference here is that all strategies interact but the information strategy is actually an information systems or information technology strategy.

Boddy, Boonstra, and Kennedy (2002, p. 93) reference an information strategy (Figure 6) where they acknowledge that "it is easy to imply, in view of its importance [that is information], managers should develop a clear information strategy .......this is in practice extremely challenging." However, their discussion predicates an information systems strategy not information per se but acknowledges that issues are related to formulating an information strategy. Again, there seems to be a blended approach to information systems and information strategy formulation. They do view the information strategy in the same terms as any other strategy, as a function of the organisation.

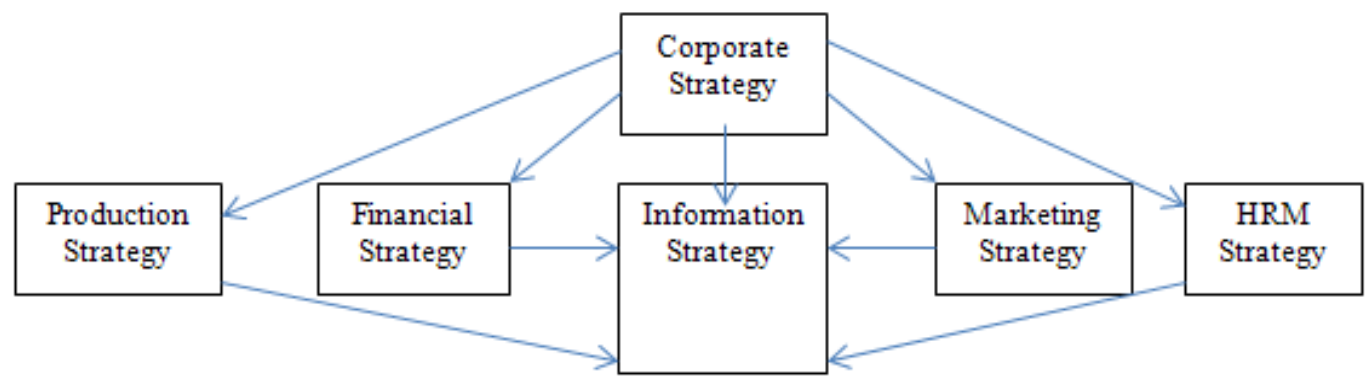

Figure 6: Boddy, Boonstra , and Kennedy - An Information Strategy

Source: Boddy, Boonstra, \& Kennedy, 2002, p. 94

The previous strategies infer that information is a result of everything flowing through all aspects of the organisation. The view of 'flowing' through other strategies or functions resonates with Davenport, Eccles, and Prusak (1992) who stress that managing information is a political process. They use the analogy of 'information politics' as a means to understanding and managing information. Although there is no specific reference to an information strategy per se, the discussion, in terms of managing information, acknowledges the various types and structures that deal with information and highlights the difficulty of managing this resource. 
Other authors namely, Neyland and Surridge (2002, p. 10) provide a more transient view of an information strategy by suggesting that there is no universal answer as to what it is but suggest that it may be "an ongoing process, not dependent on a single document or committee." This view of uncertainty and ambiguity seems endemic, even since Allen and Wilson (1996, p. 247) argued the term information strategy was confusing. They go on to acknowledge the interchangeable nature of the term, by stating that it is often used to mean different things to different individuals, i.e., "at times it is used to mean information systems strategy, at times information technology strategy, and on other occasions, information management strategy." Allen and Wilson (1997, p.179) also argued that there has been too great a focus on the technologies, on internal institutional factors and not on the processes, by stating that in "the late 1980s and early 1990s HEIs developed strategic plans which were information technology focused.....over 73\% of these were perceived to have either failed or been only partially successful." They describe problems in formulating information strategies as a result of terminological mismatch, meaning that there were many different terms being used, all ascribing to the same phenomenon - information. This reference to inconsistency is also highlighted by Mocker and Teubner (2005) and again in 2009 by Teubner and Mocker (p. 148) by acknowledging that "as long as a common concept of information strategy is lacking .... the process will remain vague."

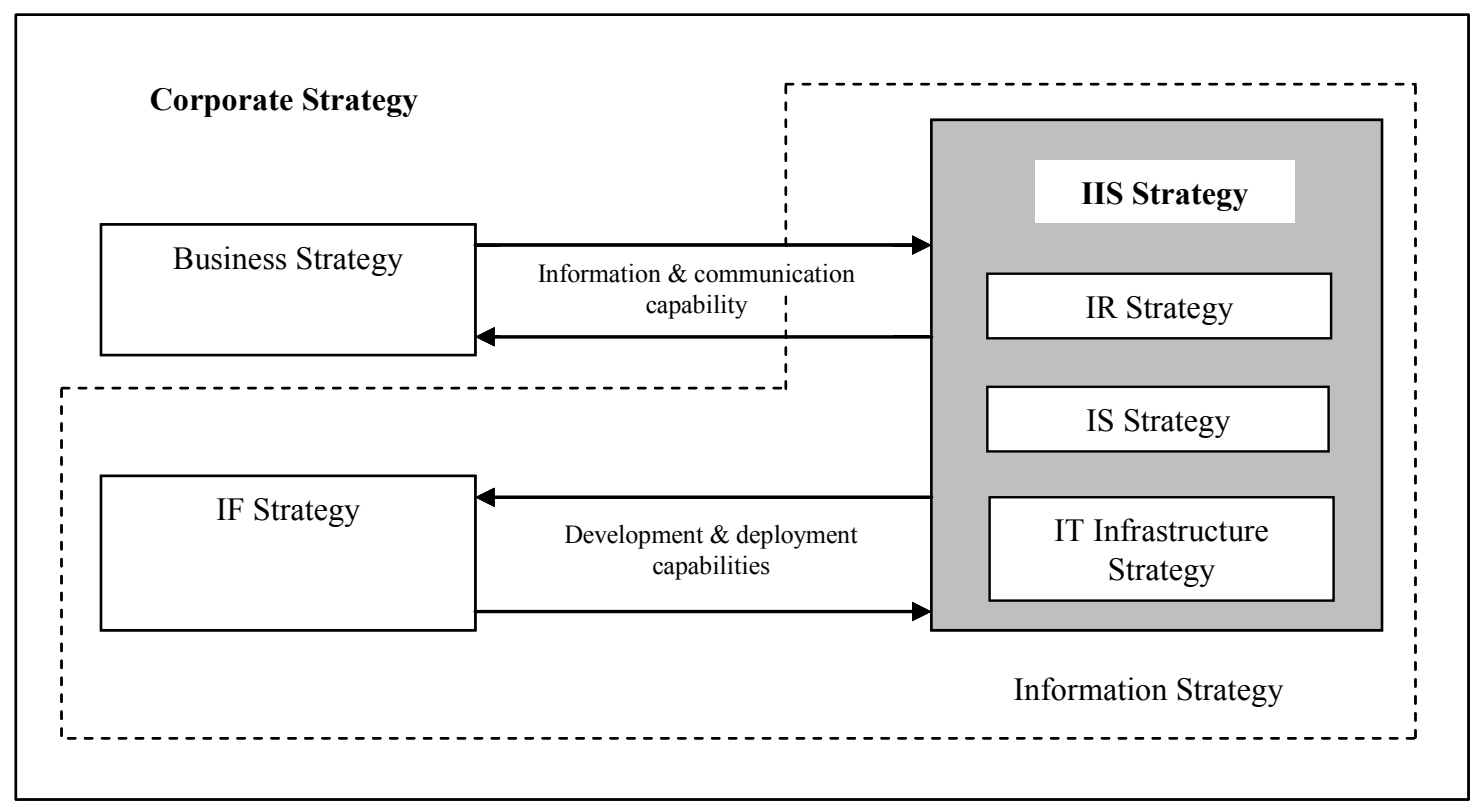

Figure 7: Teubner and Mocker's overall model of information strategy

(Source: Teubner and Mocker, 2009,p. 162)

Teubner and Mocker (2009) provide their interpretation of an information strategy, in Figure 7. However, the interpretation of an information strategy again focuses upon the areas of IIS and IF (information infrastructure and information function). These two areas coincide with Earl's view of information technology strategy, information system strategy, and an information management strategy. Where the IIS strategy contains information resources, information technology, and information communication systems and the IF contains tasks to plan, build, run, and maintain and further develop the IIS, the notion that the IIS strategy influences the IF strategy, so the notion of 'nesting' or strategies 'flowing into' one another seems to be inferred, indicating that the information strategy is not a strategy per se but acts as an overarching process that is encapsulated by the two contained strategies (IF \& IIS). This view of it working in conjunction with the business strategy is not unusual within the IS literature (Scholes, 2001). The view of an information strategy working in isolation may be appropriate at operation levels, but not at a strategic level. At 
the strategic level being disconnected from the wider organisational strategies is a danger; indicating the influence and relationship between wider organisational strategies is an important focus.

What can be drawn from the IS literature is a sense that much of the work towards information strategies is implicit, in that it is identified as part of other actions or strategy formulation processes. Often this leaves more questions than answers and seems to lack completeness, structure or rationale. The information strategy is seen as a planning process (Porter \& Millar 1985), as a function along with other organisational function (Boddy, Boonstra, \& Kennedy, 2005; Mocker \& Teubner, 2005; Smits, Van der Poel, \& Ribbers, 1997), or as systems development process focussed upon gaining competitive advantage. What is apparent is that all authors have a contribution to make, but there seems to be little consensus on the issues that encapsulate the notion of an information strategy. Many of these views are driven by the assimilation of information as being something that can be processed or manipulated by technology. This inference of an information strategy as being used as a mechanism to manage this 'resource' identifies why the notion of information and an information strategy resonated within the domain of information resource management and with those from the information technology and information systems domains.

\section{Research Narrative}

In taking all of the previous discussion on general merit it seems prudent to identify how this research has evolved. The author had access to a senior management committee, within a higher education establishment. This committee was termed the 'information steering committee' and its members were all individuals holding senior management roles within the institution. The remit of the committee was to formulate an information strategy. What has transpired within the realms of higher education is not unrelated or that different from what has happened within business and organisational contexts, in general, with regards to the formulation of an information strategy. The author has had a long and involved relationship with a number of higher education institutions and this has provided both access to and a network of facilities. The research is based upon historical documentation, minutes of meetings, email correspondence, interviews (seventeen), and public domain material. Interview material was collected, and the author then used the process of content analysis, contingency tables, correspondence analysis, and perceptual mapping as a mechanism of identifying themes in terms of understanding the information strategy formulation process. Along-side this data collection process the author also carried out a broad sweep of higher education institutions (HEIs) public domain data, on three separate occasions. This occurred in three distinct phases and as outlined in Appendix A. Initially, the data was collected when the notion of an information strategy was in essence new, vibrant, and on the agenda of many HEIs, that is in the early 2000s. This was then repeated sometime later with the aim of identifying had this involvement and focus on managing information and formulating an information strategy actually reached fruition. Again, this process was revisited to see where these institutions were in terms of a better understanding of information and whether or not they had a 'working', 'accessible' approach to managing information, i.e., an information strategy.

Figure 8 identifies part of the process that this research took in identifying themes from interview material and perceptual mapping. The author has used Hirschheim and Klein's (1989) four paradigms of information systems development model as a mechanism to link interview material, content analysis and view/theme generation with individual information steering committee members. What this highlights is the very hard and objectivist view that seemed to be prevalent within the committee with regards to both the notion of information and its subsequent impact on the information strategy formulation process. What is suggested by Figure 8 (Knox, 2013) is that the majority of individuals are aligned with specific disciplines, that individuals that have strong tendencies towards descriptive, logically sequenced, and a hard interpretation of information. 
Ultimately, the author would argue that the positioning of individuals, within the framework, indicates both similarities and differences between individual perceptions of an information strategy. This discipline alignment and individual perception highlights why there are discrepancies and ambiguity regarding the notion of an information strategy.

Following on from the above narrative, Appendix B highlights a selection of responses, from interviewees, that allowed the process of content analysis and contingency tables to be used in formulating themes that assisted in understanding the notion of an information strategy.

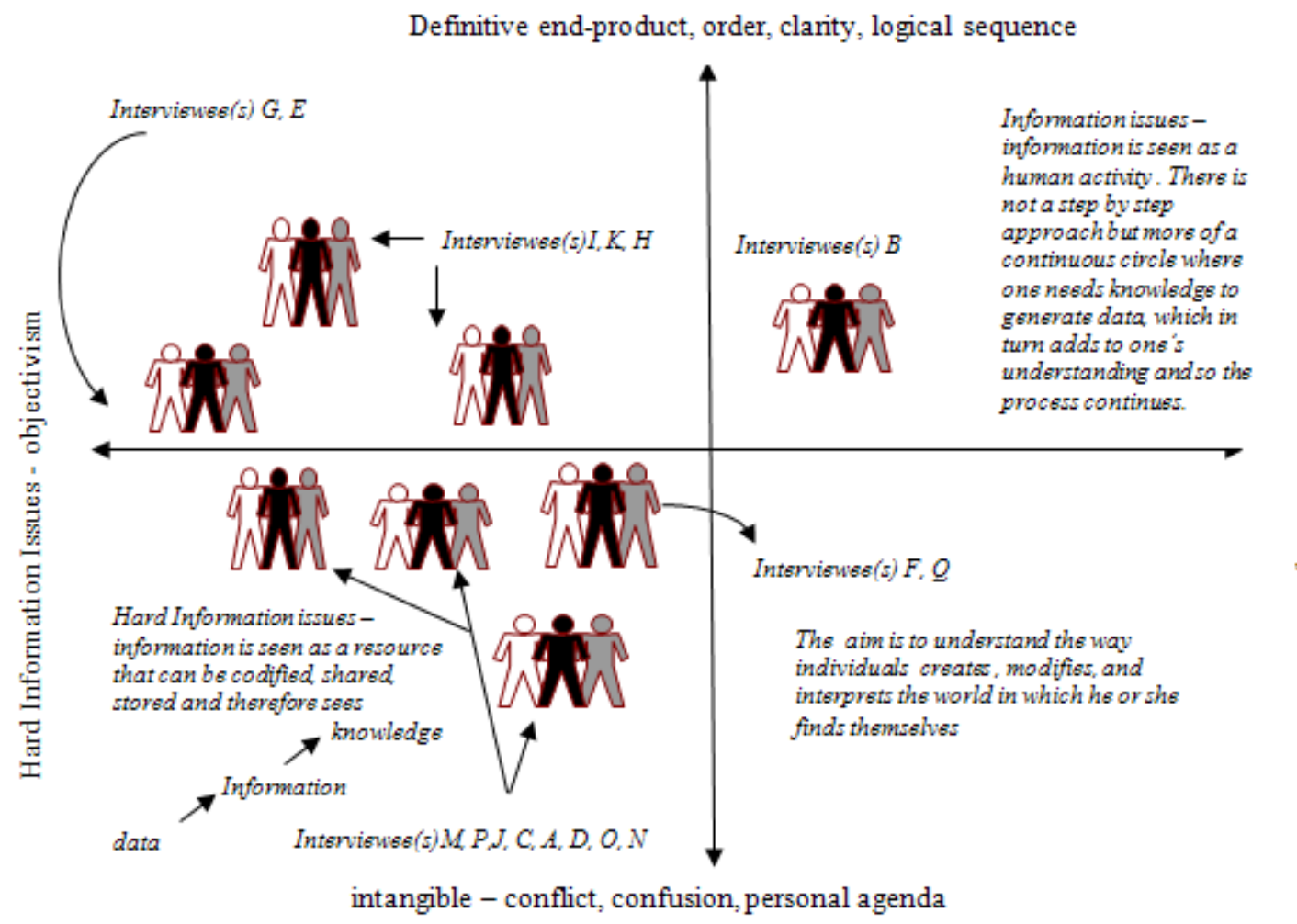

Figure 8: Perceptual Mapping of individuals and their views of information and an information strategy. (Source: Knox, 2013, p. 159)

Unfortunately, the reality was that very few higher education institutions actually identified a document referred to as an information strategy. Even more enlightening was the fact that not one institution had this 'strategy' available for viewing, promoting the notion that institutions had either 'shelved' their involvement with formulating an information strategy or had a strategy under another guise that was not necessarily in line with addressing the notion of information. This then supported the previous view, raised by the author, that institutions tended to follow a 'placation' approach to information strategy formulation. If this view is further supported then it could be argued that this contradicts the generally accepted importance that institutions, businesses and academia have placed on the role of information and the formulation of an information strategy. If information is so vital to businesses, as Kroenke (2007, p. 11) argues, that "information is a difference that makes a difference" it seems that for institutions to 'shelve' or 'ignore' the notion of an information strategy could be both detrimental and fundamentally against what businesses and organisations are trying to achieve. 


\section{Overview and Concluding Remarks}

This research paper has focused upon information and the notion of an information strategy from an information systems perspective. It has also provided some understanding as to why discipline approaches impact on information strategy formulation as seen through the lens of library and information science and general management.

A general view, within the information systems discipline, acknowledges that an information strategy is "a plan with a defined timeframe setting information management objectives and tactics and control to achieve them" (Chaffey \& Wood, 2005, p. G7). This indicates a time element, an end point, and an inference that there is clear view of what an information strategy is meant to achieve. There seems to be, within the information systems discipline, an elected affinity of aligning 'information' with technology, systems and resourced based issues. This may be somewhat naïve as many information systems do not provide the appropriate or necessary information that management require. Guan, Nunez, and Welsh (2002, p. 170) argue that the "existing information technology infrastructures at many organisations are inadequate to meet the needs of institutional decision-makers."

It could be argued, from the information systems discipline perspective, that the concept of an information strategy was based on trying to extract the benefits of 'information' using the importance placed upon technology and the power of technology as a catalyst. This infers that information technology and systems provide access to information and those tasked with managing the technology are seen as custodians of information. Hence, why there is a correlation between individuals tasked with formulating an information strategy and the notion of an information strategy is seen to be. The notion of an information strategy, from the literature, seems to indicate that it is not a 'straight forward' strategy and one that has various interpretations making it both complex and controversial.

Part of this, the author would argue, is that the information strategy seems to be enmeshed with other strategies, namely the information technology strategy, the information systems strategy, and the information management strategy; it seems prudent, at this stage, to acknowledge that from an information systems perspective the notion of an information strategy has not been forthcoming but is inferred to exist within other related strategies. It is, however, intrinsically different to traditional strategies that organisations have had to deal with in the past. The contentious nature of the strategy, the intangible nature of the resource, and the reasoning for having the strategy all contribute to its complexity and ambiguity.

As Wijnhoven $(2009$, p. 2) argues "information is a key resource for strategic and operational processes in organisations" and Earl (2000, p. 22) indicates that "more and more businesses are defining their strategies in terms of information or knowledge." The author would argue that within the information systems discipline the term information strategy focuses upon the management and formulation of a tangible resource.

Further research would involve expanding the views found within library and information science and general management disciplines to act as a corollary for what has been identified within the information systems discipline.

In terms the of information systems discipline it seems apparent that the evidence indicates a level of ambiguity prevails and infers why the decision-making process within many higher education institutions has become vague, ineffectual, and ultimately not existent in terms of information strategy formulation.

\section{References}

Ackoff, R. L. (1967). Management misinformation systems. Management Science, 14(4), 147-156. 
Allen, D. K. (1995). Information systems strategy formation in higher education institutions. Information Research, 1(1), 12 - 19.

Allen, D. K., \& Wilson, T. D. (1996). Information strategies in UK higher education institutions. International Journal of Information Management, 16(4), 239 - 251.

Allen, D. K., \& Wilson, T. D. (1997). Information systems strategy formulation in higher education. In Understanding Information Policy: Proceedings of a British Library funded Information Policy Unit Workshop, Cumberland Lodge, UK, 22 - 24 July 1997, Bowker Saur.

Allen, D. K., \& Wilson, T. D. (2003). Vertical trust/mistrust during information strategy formation. International Journal of Information Management, 23, 223-237.

Asprey, L. (2004). Information strategies: Are we aligning the business case with enterprise planning? Records Management Journal, 14(1), 7 - 13.

Athique, A. (2013). Digital media and society. Cambridge: Polity.

Belanger, F., \& Van Slyke, C. (2012). Information systems for business: An experiential approach. Hoboken, NJ: John Wiley \& Sons.

Beynon-Davies, P. (2009). Business information systems. Basingstoke: Palgrave Macmillan.

Boddy, D., Boonstra, A., \& Kennedy, G. (2002). Managing information systems: An organisational perspective. Harlow, Pearson Education Limited.

Boddy, D., Boonstra, A., \& Kennedy, G. (2005). Managing information systems: An organisational perspective (2nd. ed). Harlow, Pearson.

Boland, R. J. (1987). The in-formation of information systems. In R. J. Boland \& R. A. Hirschheim (Eds), Critical issues in information systems (pp: 363 -379). New York, NY: John Wiley \& Sons.

Chaffey, D., \& White, G. (2011). Business information management (2nd ed.). Harlow, England: Pearson Education.

Chaffey, D., \& Wood, S. (2005). Business information management: Improving performance using information systems. Harlow: Prentice Hall, Pearson Education Limited.

Cole, G. A., \& Kelly, P. (2011). Management theory and practice (7th ed.). Andover, Hampshire, SouthWesternCengage.

Currie, W., \& Galliers, B. (Eds.). (1999). Rethinking management information systems: An interdisciplinary perspective. Oxford: Oxford University Press.

Davenport, T. H. (1997). Information ecology. Oxford: Oxford University Press.

Davenport, T. H. (2000). Putting the I in IT. In D. A. Marchand, T. H. Davenport, \& T. Dickson, Mastering information management. London: Prentice Hall.

Davenport, T. H., Eccles, R. G., \& Prusak, L. (1992). Information politics. Sloan Management Review Fall 34(1), 53-65.

Dhillon, J. K. (2001). Challenges and strategies for improving the quality of information in a university setting: a case study. Total Quality Management, 12(2), 167-177.

Drucker, P. F. (1969). The age of discontinuity: Guidelines to our changing society. New York: Harper and Row.

Drucker, P. F. (2002). Managing in the next society. Oxford: Butterworth-Heinemann.

Duff, A. S. (2002). The status of information society studies in the information science curriculum. Library Review, 51(3/4), 139 - 148.

Earl, M. J. (1988). Information management: The strategic dimension. Oxford: The Claredon Press.

Earl, M., J. (1989). Management strategies for IT. London: Prentice Hall.

Earl, M., J. (2000). Every business is an information business. In D. A. Marchand, T. H. Davenport, \& T. Dickson (Eds.), Mastering information management. London: Prentice Hall. 
Galliers, R. D. (1991). Strategic information systems planning: Myths, reality and guidelines for successful implementation. European Journal of Information Systems, 1(1), 55 - 64.

Galliers, R. D. (1993). Towards a flexible information architecture: integrating business strategies, information strategies and business process redesign. Journal of Information Systems, 3, 193 - 213.

Goldschmitt, R. (2004). Thinking beyond digital libraries - Designing the information strategy for the next decade. 7th International Bielefeld Conference 2004, Emerald Publishing Limited.

Guan, J., Nunez, W., \& Welsh, H. F. (2002). Institutional strategy and information support: The role of data warehousing in higher education. Campus-Wide Information Systems, 19(5) 168-174.

Hall, H. (1994). Information strategy and manufacturing industry - Case studies in the Scottish textile industry. International Journal of Information Management, 14, 281 - 294.

Harris, T. G. (1993). The post-capitalist executive: An interview with Peter F Drucker. Harvard Business Review, 71(3), 115-122.

Hirschheim, R., \& Klein, H. K. (1989). Four paradigms of information system development. Communications of the ACM, 32(10), 1199-1216.

Joint-Funding-Councils-Libraries-Review-Group (1993). Joint Funding Council's Libraries Review Group Report - Follett, B., Sir, http://www.ukoln.ac.uk/services/papers/follett/report/ch8.html.: Chapter 8.

Joint-Information-Systems-Committee (1995a). Information strategy - An executive briefing, JISC Publication.

Joint-Information-Systems-Committee (1995b). Guidelines for developing an information strategy - The sequel (a practitioners guide). JISC Publication..

Joint-Information-Systems-Committee (1998a). JISC information strategies: An executive briefing. Joint Information Systems Council.

Joint-Information-Systems-Committee (1998b). Guidelines for developing an information strategy: The sequel. Bristol, Joint Information Systems Committee.

Joint-Information-Systems-Committee (2004). Information as a strategic resource. JISC Consultation Workshop, Belfast..

Jordan, E., \& Tricker, B. (1995). Information strategy: Alignment with organisation structure. Journal of Strategic Information Systems, 4(4), 357-382.

Keen, J., \& Muris, N. (1995). Information strategy in the NHS: issues and challenges. Journal of Management in Medicine, 9(2), 57-62.

Knox, K. T. (2009). Information and informing science. In T. G. Gill \& E. Cohen (Eds.), Foundations of Informing Science: Overview, elements and perspectives 1998 - 2008. Santa Rosa, California, Informing Science Press.

Knox, K. T. (2013). Constructing an 'information strategy' in higher education: Perceptions, structure and action. Nottingham Business School. Nottingham, Nottingham Trent University: PhD Thesis: pp 309.

Kroenke, D. M. (2007). Using MIS. Upper Saddle River, New Jersey: Pearson, Prentice Hall.

Law, D., MacGregor, G., McCulloch, E., \& Wallis, J. (2005). Developing a national information strategy in Scotland. Caldernos de Biblioteconomia, Arquivistica de Documentacao, 1, 49-53.

Library-Association. (1996). New research shows business fails to manage information effectively. Information for Business, 3, 1 - 2.

Macmillan, M. (1997). Managing information systems: Three key principles for general managers. Journal of General Management, 22(3), 12 - 23.

Marchand, D. (1997). Competing with information: Knowing what you want. FT Mastering Management Reader, July/August. 
Mocker, M., \& Teubner, A. (2005). Towards a comprehensive model of information strategy. 13th European Conference on Information Systems, information systems in rapidly changing economy - ECIS 2005, Rehensburg, Germany.

Mutch, A. (2008). Managing information and knowledge in organisations: A literacy approach. London: Routledge.

Neyland, D., \& Surridge, C. (2002). The contest for information strategy: Utilising an alternative approach to produce "good management practice. Retrieved 28 May 2003, 2003, from http://www.strategyworldcongress.org/neyland.htm.

Orna, E. (1999). Practical information policies. Aldershot: Gower Publishing Limited.

Pearlson, K. E. (2001). Managing and using information systems - A strategic approach. John Wiley \& Sons.

Pearlson, K. E., \& Saunders, C. (2010). Managing and using information systems: A strategic approach (4th ed.). Hoboken, New Jersey: John Wiley \& Sons.

Pearlson, K. E., \& Saunders, C. S. (2013). Strategic management of information systems. Hoboken NJ: John Wiley \& Sons.

Peppers, D., \& Rogers, M. (2011). Managing customer relationships (2nd ed.). Hoboken, New Jersey: John Wiley \& Sons.

Porter, M. E., \& Millar, V. E. (1985). How information gives you competitive advantage. Harvard Business Review, 63(4),149 - 160.

Scholes, K. (2001). Information, IT and strategy. The Journal of Economics and Business Education, 5(2), $24-31$.

Smits, M. T., Van der Poel, K. G., \& Ribbers, P. M. A. (1997). Assessment of information strategies in insurance companies in the Netherlands. Journal of Strategic Information Systems, 6(2), 129 - 148.

Stahl, B. C. (2006). On the difference or equity of information, misinformation, and disinformation: A critical research perspective. Informing Science: The International Journal of an Emerging Transdiscipline, 9, 83 - 96. Retrieved from http://www.inform.nu/Articles/Vol9/v9p083-096Stahl65.pdf

Teubner, A., \& Mocker, M. (2009). Information strategy - Towards a comprehensive model of information strategy. In R. D. Galliers \& D. E. Leidner (Eds.), Strategic information management: Challenges and strategies in managing information systems (Chapter 6, pp. 147-170). New York \& London, Routledge.

Wijnhoven, F. (2009). Information management: An informing approach. Abingdon, Oxon: Routledge.

Wilson, T. D. (1986). Information needs in social services: An overview. Research Highlights in Social Work, 13, 12 - 24. Retrieved from http://www.informationr.net/tdw/publ/papers/infoneeds85.html

Wilson, T. D. (1989). The implementation of information systems strategies in UK companies: Aims and barriers to success. International Journal of Information Management, 9(4), 245 - 258.

Wilson, T. D. (2001). Information strategy in higher education. ISEGI Seminar, Universidade Nova de Lisboa, March, 2001.

\section{Appendices}

The following appendices identify the research data that has been collected.

Appendix A identifies the environment scan of public domain material that the author undertook as a means of identifying the notion of an information strategy in a variety of higher education institutions. The material has undergone a process of redaction to ensure anonymity and confidentially for the individual institutions.

Appendix B identifies interviewee responses which assisted in both theme generation and the perceptual mapping process. 
Appendix A - Environmental Scan of Institutional Web sites to identify the use and reference to an information strategy

\begin{tabular}{|c|c|c|c|c|c|}
\hline \multirow[t]{2}{*}{ Institution } & \multirow[t]{2}{*}{ Working Environment } & \multirow[t]{2}{*}{ Brief Descriptor - strategic information initiatives } & \multicolumn{3}{|c|}{ Information Strategy } \\
\hline & & & 2004 & 2008 & 2013 \\
\hline Institution A1 & $\begin{array}{l}\text { - } \quad \text { Boutique' university with } \\
10,922 \text { ( } 8,500 \text { EFTSU) students } \\
\text { and } 2200 \text { staff. } \\
\text { Strong research focus. Main } \\
\text { campus is just } \\
\text { - } \quad \text { invited to develop a campus in }\end{array}$ & $\begin{array}{l}\text { Information Management strategy is based around need to ask who is the information } \\
\text { owner, and organisation of information into coherent clusters } \\
* * \text { As at } 2013 \text { there is a statement in the University Strategy } 2013-16 \text {, indicating that } \\
\text { we ensure they can gain access to the information they need whenever and wherever } \\
\text { they might need it. The need to collect and disseminate information appropriately is } \\
\text { stated in their research and people strategies. }\end{array}$ & $\checkmark$ & $\begin{array}{l}\text { Has a } \\
\text { statement - } \\
\text { information } \\
\text { is managed } \\
\text { as a strate- } \\
\text { gic resource } \\
\text { to underpin } \\
\text { every facet } \\
\text { of activity }\end{array}$ & $* * \checkmark$ \\
\hline Institution A2 & $\begin{array}{l}\text { Single site campus - } 33 \text { acre } \\
\text { campus in the centre of } \\
\text {. As at } 2000 \text { student enrol- } \\
\text { ments were } 16700 \text { and staff } \\
2100\end{array}$ & $\begin{array}{l}\text { Based on Principles-Strategy-Actions-Agents model. Information Strategy managed by } \\
\text { ISG, and seen as at a higher level than the IT Strategy. Detailed, well produced, distrib- } \\
\text { uted to all staff, but largely ineffective (product is fine, but the process doesn't deliver). } \\
\text { They argue that it needs to be embedded in university and owned by DVC(I). }\end{array}$ & $\mathbf{X}$ & $\begin{array}{c}\text { No informa- } \\
\text { tion strategy } \\
\text { but does } \\
\text { have an } \\
\text { information } \\
\text { literacy } \\
\text { strategy - } \\
2005\end{array}$ & $\mathbf{X}$ \\
\hline Institution A3 & - $\quad$ Mid sized university & $\begin{array}{l}\text { The theme that information is available in ever greater forms - the aim is to provide } \\
\text { access to, develop competence in the handling of, all relevant forms. The university will } \\
\text { seek to provide access to any information which is needed for its effective functioning, } \\
\text { and to maximise the extent to which a common infrastructure, with common facilities, is } \\
\text { available for this. } \\
\text { The assumed time scale for this strategy is five years }\end{array}$ & $\mathbf{X}$ & $\begin{array}{l}\text { No mention } \\
\text { of an infor- } \\
\text { mation } \\
\text { strategy } \\
\quad \mathrm{X}\end{array}$ & $\mathbf{X}$ \\
\hline Institution A4 & $\begin{array}{l}\text { Dual Campus University - } \\
\text { comprising } 8 \text { sites in and } \\
\text { around } \quad \text {-arising out } \\
\text { recent }\end{array}$ & $\begin{array}{l}\text { Most of the focus to date on Information Systems (as part of the Information sub- } \\
\text { strategy). Still sorting out org. structures post-merger. Information Steering Group } \\
\text { (which was driving things) went into hibernation when it lost its champion }\end{array}$ & $\mathbf{X}$ & $\begin{array}{l}\text { not in the } \\
\text { public do- } \\
\text { main } \\
\text { X }\end{array}$ & $\mathrm{X}$ \\
\hline
\end{tabular}




\begin{tabular}{|c|c|c|c|c|c|}
\hline \multirow[t]{2}{*}{ Institution } & \multirow[t]{2}{*}{ Working Environment } & \multirow[t]{2}{*}{ Brief Descriptor - strategic information initiatives } & \multicolumn{3}{|c|}{ Information Strategy } \\
\hline & & & 2004 & 2008 & 2013 \\
\hline Institution A5 & $\begin{array}{ll}\text { - } & 21129 \text { students } \\
\text { - } & \text { staff }\end{array}$ & $\begin{array}{l}\text { Strategy focuses mostly on technology, despite claims to the contrary. Information Strat- } \\
\text { egy Board (ISB) now manages it, but is felt to make decisions without regard of techni- } \\
\text { cal issues. Strategy felt not to be working at level of individual staff. } \\
\text { The corporate plan for 1999-2004 included the development of a formal information } \\
\text { strategy, to improve the quality and effectiveness of data and information required for } \\
\text { the operation of the university; the information strategy should provide a clear, agreed } \\
\text { and efficient means of: acquiring, validating, securing, storing, manipulating, analysing, } \\
\text { retrieving, disseminating, archiving and, when appropriate, destroying information in } \\
\text { support of all aspects of the university's work. } \\
\text { Some of the most challenging areas in relation to the information strategy concern the } \\
\text { allocation of resources. }\end{array}$ & $\chi$ & $\begin{array}{l}\text { Uses the } \\
\text { information } \\
\text { services } \\
\text { strategy as a } \\
\text { mechanism } \\
\text { to identify } \\
\text { other strate- } \\
\text { gies - as at } \\
\text { July } 2007 \text {, } \\
\text { near comple- } \\
\text { tion of the } \\
\text { info strategy } \\
\text { - but not in } \\
\text { the public } \\
\text { domain }\end{array}$ & $\begin{array}{l}\text { Info. Ser- } \\
\text { vices strategy } \\
2007-12 \text { and } \\
\text { Info systems } \\
\text { security and } \\
\text { interception } \\
\text { policy - } \\
\text { neither of } \\
\text { which are an } \\
\text { info strategy } \\
\text { X }\end{array}$ \\
\hline Institution A6 & $\begin{array}{l}\text { based over campuses, } \\
\text { five in the } \quad 8000 \text { students and staff } \\
\text { - } \quad \text { Became a } \\
\text { and a }\end{array}$ & $\begin{array}{l}\text { They have a strategy - http://www ac.uk/general information -strategy. shtml - } \\
\text { responsibility went to Deputy VC, Heads of Departments, Service director, Deans of } \\
\text { faculty, PL in information systems, membership changed considerably over the period } \\
\text { taken to form the strategy. Top down approach, Tried and failed to follow JISC, view of } \\
\text { information as an institutional rather than an individual resource. Strategy not imple- } \\
\text { mented }\end{array}$ & $\checkmark$ & $\begin{array}{l}\text { The informa- } \\
\text { tion systems } \\
\text { strategy } \\
\text { supports the } \\
\text { information } \\
\text { strategy - } \\
\text { based on } \\
\text { JISC \& the } \\
\text { Follet Report }\end{array}$ & $\begin{array}{l}\text { No mention } \\
\text { of the info } \\
\text { systems } \\
\text { strategy } \\
\text { previously } \\
\text { seen on the } \\
\text { website }\end{array}$ \\
\hline Institution A7 & - $\quad 23465$ students & $\begin{array}{l}\text { Very much an IT led strategy initially, attempts to bring it in line with other strategies } \\
\text { which are occurring within the university. Currently in consultation with Faculty heads } \\
\text { as to what information is needed to operate their area. Initially the information was seen } \\
\text { as a key resource }\end{array}$ & $\begin{array}{l}\text { There is } \\
\text { a com- } \\
\text { mitment } \\
\text { to an } \\
\text { infor- } \\
\text { mation } \\
\text { strategy } \\
\checkmark\end{array}$ & $\begin{array}{l}\text { not in the } \\
\text { public do- } \\
\text { main } \chi\end{array}$ & $\begin{array}{l}\text { Not men- } \\
\text { tioned or in } \\
\text { the public } \\
\text { domain }\end{array}$ \\
\hline Institution A8 & $\begin{array}{l}\text { The has approx. } \\
\text { the UK } \\
\text { - } 220000 \text { students }\end{array}$ & $\begin{array}{l}\text { Strategy focuses mostly on technology, despite claims to the contrary. Information Strat- } \\
\text { egy Board (ISB) now manages it, but is felt to make decisions without regard of techni- } \\
\text { cal issues. Strategy felt not to be working at level of individual staff. The university has } \\
\text { no information strategy per se }\end{array}$ & $\mathbf{x}$ & $\begin{array}{l}\text { Has doc. } \\
\text { version is } \\
2004- \\
\text { doesn't ad- } \\
\text { dress info. }\end{array}$ & $\mathbf{x}$ \\
\hline
\end{tabular}




\begin{tabular}{|c|c|c|c|c|c|}
\hline \multirow[t]{2}{*}{ Institution } & \multirow[t]{2}{*}{ Working Environment } & \multirow[t]{2}{*}{ Brief Descriptor - strategic information initiatives } & \multicolumn{3}{|c|}{ Information Strategy } \\
\hline & & & 2004 & 2008 & 2013 \\
\hline Institution A9 & $\begin{array}{l}\text { A campus with } \\
19,000 \text { students and } 800 \text { aca- } \\
\text { demic staff ( } \\
\text { Small institution located in } \\
\text { socially deprived }\end{array}$ & $\begin{array}{l}\text { Embedded in Strategic Planning processes for university. Acknowledgements that in } \\
\text { trying to create an information strategy, they may in-fact concentrate on current informa- } \\
\text { tion problems - for which they don't have a solution, instead of focusing on the strategic } \\
\text { info needs of the university community. Problems occurred during their implementation } \\
\text { stage. Also a realisation that Information Systems and Information technology issues are } \\
\text { of secondary importance to the University's Information needs } \\
\text { Part of the JISC exemplar case studies institutions }\end{array}$ & $\mathbf{X}$ & $\begin{array}{l}\text { not in the } \\
\text { public do- } \\
\text { main, noth- } \\
\text { ing relating } \\
\text { to informa- } \\
\text { tion strategy } \\
\text { found when } \\
\text { searched } \\
\chi\end{array}$ & $\begin{array}{l}\text { Policies } \\
\text { relate to info } \\
\text { governance } \\
\text { only } \\
\mathrm{X}\end{array}$ \\
\hline Institution B1 & $\begin{array}{ll}\text { - } & 18 \text { Departments, } \\
\text { - } & 30 \text { Research Centres and insti- } \\
\text { tutes } \\
\text { - } \\
7000 \mathrm{f} / \mathrm{t} \text { students and } 8000 \mathrm{in} \\
\text { total }\end{array}$ & $\begin{array}{l}\text { Never came back or responded to repeated requests for evidence of their activities relat- } \\
\text { ing to information strategy formulation. Subsequently, they are acknowledged but did } \\
\text { not contribute to the research process. }\end{array}$ & $\mathbf{X}$ & $\begin{array}{l}\text { No mention } \\
\text { of informa- } \\
\text { tion strategy; } \\
\text { only infor- } \\
\text { mation sys- } \\
\text { tems group, } \\
\text { and module } \\
\text { MG209- } \\
\text { strategy \& } \\
\text { info in title - } \\
\text { not in the } \\
\text { public do- } \\
\text { main } \chi\end{array}$ & $\mathbf{X}$ \\
\hline Institution B2 & $\begin{array}{l}\text { - } \quad \text { Research oriented } \\
\text { - } \quad 5000 \text { students, made up of both } \\
\text { home and international students } \\
\text { - } \quad \text { based }\end{array}$ & $\begin{array}{l}\text { Currently have the process of information strategy as one of their top-level strategies, } \\
\text { forming part of the overall strategic plan of the university. Developing through an in- } \\
\text { formation strategy group, consisting of VC principal, Pro VC, Director of Finance, Aca- } \\
\text { demic representatives, president of the student union, director of computing and his } \\
\text { policy manager, and head of library services. Reviewed other strategies from the UK and } \\
\text { abroad, plus JISC - implementation through control of the purse strings, interconnectiv- } \\
\text { ity with other strategies }\end{array}$ & $\checkmark$ & $\begin{array}{l}\text { "information } \\
\text { should be } \\
\text { available and } \\
\text { accessible to } \\
\text { all" June } \\
2003 \text { - not in } \\
\text { the public } \\
\text { domain }\end{array}$ & $\begin{array}{l}\text { No longer } \\
\text { mentioned in } \\
\text { the strategic } \\
\text { plan }\end{array}$ \\
\hline Institution A10 & \begin{tabular}{ll} 
- & \multicolumn{1}{c}{ campuses -} \\
- & The majority of students $1 / 3$ - \\
come from \\
- & University status 1999
\end{tabular} & $\begin{array}{l}\text { Currently have an info strategy. Responsibility went to Head of school, IT director, Head } \\
\text { of Computing and IT - and a steering group. Loosely followed JISC and based on other } \\
\text { institutions - strategy based on an external report mixture of top down and bottom up. }\end{array}$ & $\checkmark$ & $\begin{array}{l}\text { Not identi- } \\
\text { fied in the } \\
\text { public do- } \\
\text { main }\end{array}$ & $\begin{array}{l}\text { Last men- } \\
\text { tioned of info } \\
\text { strategy was } \\
2010\end{array}$ \\
\hline
\end{tabular}




\begin{tabular}{|c|c|c|c|c|c|}
\hline \multirow[t]{2}{*}{ Institution } & \multirow[t]{2}{*}{ Working Environment } & \multirow[t]{2}{*}{ Brief Descriptor - strategic information initiatives } & \multicolumn{3}{|c|}{ Information Strategy } \\
\hline & & & 2004 & 2008 & 2013 \\
\hline Institution A11 & $\begin{array}{l}\text { two main centre - } \quad \text { and } \\
\text { - } \quad 7 \text { faculties }- \\
\text { - } \quad 23000 \text { students and } 3300 \text { staff }\end{array}$ & $\begin{array}{l}\text { They do have in place a strategy, have had one in one form or another since } 1985 \text {, latest } \\
\text { version is } 2001 \text {, developed by the information services and systems committee of the } \\
\text { institution. Developed via a broad vision and objective statement by the team and vali- } \\
\text { dated. Very bottom up exercise, groups from across the university inputting and im- } \\
\text { provements that were then concatenated into a final list of priorities for the period } 2002 \text { - } \\
2006 \text {. Followed JISC guidelines broadly speaking, reviewing consists of a list of work } \\
\text { that is completed on a year by year basis }\end{array}$ & $\checkmark$ & $\begin{array}{l}\text { Incorporates } \\
\text { the info } \\
\text { strategy as } \\
\text { part of the } \\
\text { info systems } \\
\text { strategy - } \\
\text { assumes data } \\
\text { and info are } \\
\text { one in the } \\
\text { same }\end{array}$ & $\begin{array}{l}\text { Info security \& } \\
\text { records man- } \\
\text { agement policy } \\
\text { - data not in- } \\
\text { formation }\end{array}$ \\
\hline Institution A12 & - 12000 students, 2100 staff & $\begin{array}{l}\text { Responsibility with Director of information services, librarian and project team within } \\
\text { information services - high level committee chaired by pro vice chancellor. Developed } \\
\text { through a consultation exercise including senior staff by external consultants - draft } \\
\text { approved by executive team. Assessed by Q \& A built into all projects. }\end{array}$ & $\mathbf{x}$ & $\begin{array}{l}\text { Sees info } \\
\text { strategy and } \\
\text { info tech- } \\
\text { nology as } \\
\text { one in the } \\
\text { same }\end{array}$ & $\begin{array}{l}\text { info regulations } \\
\text { and policies - } \\
\text { data not info }\end{array}$ \\
\hline Institution A13 - CS & $\begin{array}{l}\text { - } \quad \text { Teaching led university } \\
\text { - } \quad \text { Located over } \quad \text { campuses } \\
\text { - } \quad \text { Approximately } 5500 \text { students }\end{array}$ & $\begin{array}{l}\text { There is currently an information systems strategy and an information communication } \\
\text { strategy. Interesting that there is no information strategy in the public domain given it } \\
\text { was one of JISCs case study institutions in terms of implementing and formulating an } \\
\text { information strategy. }\end{array}$ & $\checkmark$ & $\begin{array}{l}\text { not in the } \\
\text { public do- } \\
\text { main } \chi\end{array}$ & $\begin{array}{l}\text { Not in public } \\
\text { domain } \\
X\end{array}$ \\
\hline Institution A14 - CS & $\begin{array}{l}\text { - } \quad \text { A research driven university } \\
\text { - } \quad 3500 \text { staff - in total }\end{array}$ & $\begin{array}{l}\text { Identifies information as being very much in line with JISC and reiterates JISCs wording } \\
\text { in many places. Refers to information resources and identifies access to information as a } \\
\text { priority }\end{array}$ & $\checkmark$ & $\begin{array}{l}\text { Does have } \\
\text { an informa- } \\
\text { tion strategy }\end{array}$ & $\begin{array}{l}\text { Not in the pub- } \\
\text { lic domain } \\
\mathrm{X}\end{array}$ \\
\hline Institution A15 - CS & $\begin{array}{l}1995 \text { new structure }- \text { modular } \\
\text { approach } \\
12200 \text { students }\end{array}$ & $\begin{array}{l}\text { It has developed an information strategy - it is encapsulated within the framework of an } \\
\text { information management strategy (IMS) - the elements of the IMS sets a context and a } \\
\text { direction for the management of information - the principles of information manage- } \\
\text { ment, according to Hull - makes a relationship between managing information and the } \\
\text { aim to be a knowledge based institution. Nothing available as at March 2008/ or Sept } \\
2013 \text {. }\end{array}$ & $\checkmark$ & $\begin{array}{l}\text { Not in the } \\
\text { public do- } \\
\text { main } \\
X\end{array}$ & $\begin{array}{l}\text { Not in the pub- } \\
\text { lic domain } \\
\mathrm{X}\end{array}$ \\
\hline Institution A15 & $\begin{array}{l}\text { - } \quad \text { Now part of the } \\
\text { University } \\
\text { - } \quad 37000 \text { students }\end{array}$ & $\begin{array}{l}\text { Opening line of their 'information strategy framework document' identifies the aim is to } \\
\text { define good practice in relation to information management, and to determine quality } \\
\text { standards in relation to information, its communication and management But as at } \\
\text { March } 2008 \text { nothing is available }\end{array}$ & $\checkmark$ & $\begin{array}{l}\text { Not in the } \\
\text { public do- } \\
\text { main } \\
X\end{array}$ & $\begin{array}{l}\text { Not in the pub- } \\
\text { lic domain } \\
\mathrm{X}\end{array}$ \\
\hline
\end{tabular}




\begin{tabular}{|c|c|c|c|c|c|}
\hline \multirow[t]{2}{*}{ Institution } & \multirow[t]{2}{*}{ Working Environment } & \multirow[t]{2}{*}{ Brief Descriptor - strategic information initiatives } & \multicolumn{3}{|c|}{ Information Strategy } \\
\hline & & & 2004 & 2008 & 2013 \\
\hline Institution A16 - ES & $\begin{array}{l}\text { - } \\
\text { - } \\
\text { - } \\
\text { - }\end{array}$ & $\begin{array}{l}\text { There was an initial information strategy drafted in } 1995 / 96 \text {-this was in essence nothing } \\
\text { more than general principles. There was a need to provide a detailed information strat- } \\
\text { egy in the current planning period - } 1997-2001 \text {. Tied in with a new appointment of } \\
\text { PVM for communications and information technology - not sure how to implement } \\
\text { http://www. }\end{array}$ & $\checkmark$ & $\begin{array}{l}\text { Not in the } \\
\text { public do- } \\
\text { main } \\
X\end{array}$ & $\begin{array}{l}\text { The policy page } \\
\text { has a heading } \\
\text { for an info } \\
\text { strategy but } \\
\text { there is no } \\
\text { content }\end{array}$ \\
\hline Institution B3 - ES & - $\quad 30000$ students & $\begin{array}{l}\text { It does not have an information strategy per se but has both an information literacy strat- } \\
\text { egy and an information technology and systems strategy - both of which are an attempt } \\
\text { to incorporate the ethos of an information strategy }\end{array}$ & $\checkmark$ & $\begin{array}{l}\text { not in the } \\
\text { public do- } \\
\text { main } \chi\end{array}$ & $\begin{array}{l}\text { Not in the pub- } \\
\text { lic domain } \\
\mathrm{X}\end{array}$ \\
\hline Institution B4 - ES & $\begin{array}{l}\text { - } \\
\text { - } \\
\text { lwo main campuses } \\
\end{array}$ & $\begin{array}{l}\text { No information strategy is forthcoming form their website. They do have a professor of } \\
\text { information resources } \\
\text { module that is titled the same - }\end{array}$ & $\checkmark$ & $\begin{array}{l}\text { not in the } \\
\text { public do- } \\
\text { main } \chi\end{array}$ & $\begin{array}{l}\text { Not in the pub- } \\
\text { lic domain - } \\
\text { info security } \\
\text { policy } \\
\text { X }\end{array}$ \\
\hline Institution B4 & $\begin{array}{l}\text { - } \\
\text { - } \quad 15,000 \mathrm{f} / \mathrm{t} \text { students, } 3000 \mathrm{p} / \mathrm{t} \\
\text { students } \\
\text { - } \quad 4200 \mathrm{staff}-1600 \text { academic }\end{array}$ & $\begin{array}{l}\text { In } 1997 \text { the university developed an information strategy - relating to information cap- } \\
\text { ture, management and exchange; this was in response to their information technology } \\
\text { strategy developed in } 1992 \text {. It was identified that an information strategy underpinned } \\
\text { by suitable technologies would be the appropriate response. Therefore, the development } \\
\text { of an information strategy demands that functions and procedures are analysed and } \\
\text { evaluated in terms of the institution's overall strategic goals to ensure information is } \\
\text { handled in an appropriate and cost effective way. }\end{array}$ & $\checkmark$ & $\begin{array}{l}\text { There is a } \\
\text { page stating } \\
\text { there is an } \\
\text { info strategy } \\
\text { but it is not } \\
\text { in the public } \\
\text { domain }\end{array}$ & $\begin{array}{l}\text { Not in the pub- } \\
\text { lic domain } \\
\mathrm{X}\end{array}$ \\
\hline
\end{tabular}


Appendix B: interview responses that were used to generate themes surrounding information strategy formulation

\begin{tabular}{|c|c|c|c|c|c|c|c|c|c|c|c|c|c|c|c|c|c|c|c|c|}
\hline Quotes linking to themes & Occur- & & rre & ati & n & ith & In & erv & ev & $e^{\prime}$ & Re & po & ses & & & & & & & \\
\hline $\begin{array}{l}\text { 'A' - A Conflict of understanding regarding } \\
\text { the constituent elements of an information } \\
\text { strategy }\end{array}$ & & $\mathbf{A}$ & B & C & D & $\mathbf{E}$ & $\mathbf{F}$ & $\mathbf{G}$ & $\mathbf{H}$ & $\mathbf{I}$ & $\mathbf{J}$ & $\mathbf{K}$ & $\mathbf{L}$ & $\mathbf{M}$ & $\mathbf{N}$ & O & $\mathbf{P}$ & $\mathbf{Q}$ & $\mathbf{R}$ & $\mathbf{S}$ \\
\hline $\begin{array}{l}\text { IT/IS confusion - what goes in and what doesn't - what is applicable? - } \\
\text { A }\end{array}$ & $\begin{array}{l}0000000 \\
00\end{array}$ & & & $\checkmark$ & & & & & & & & & & & & & & & & \\
\hline $\begin{array}{l}\text { - For me it is what it says - it indicates how things will be achieved; it is } \\
\text { a framework" (C) }\end{array}$ & $\begin{array}{l}0000000 \\
00\end{array}$ & & & $\checkmark$ & & & & & & & & & & & & & & & & \\
\hline $\begin{array}{l}\text { - IIf you take the IT strategy - that sits within the information strategy } \\
\text { it's a strand of it BUT I am not sure that everyone would agree with } \\
\text { that" (C) }\end{array}$ & 0000000 & & & $\checkmark$ & & & & & & & & & & & & & & & & \\
\hline $\begin{array}{l}\text { - "We have either got to bite the bullet and say that 'it is asset of princi- } \\
\text { ples' or we have to say it has these strands to it and we are not clear on } \\
\text { that"(C) }\end{array}$ & 26 & & & $\checkmark$ & & & & & & & & & & & & & & & & \\
\hline $\begin{array}{l}\text { IT is terribly important and there is a tendency to regard IT as the key } \\
\text { and driving aspect of an information strategy when it isn't' BUT we do } \\
\text { need to understand why we need IT and what it might be able to de- } \\
\text { liver" (B) }\end{array}$ & & & $\checkmark$ & & & & & & & & & & & & & & & & & \\
\hline $\begin{array}{l}\text { - There is a default tendency to think of information in terms of IT and } \\
\text { IT is but one part of an information strategy" (B) }\end{array}$ & & & $\checkmark$ & & & & & & & & & & & & & & & & & \\
\hline $\begin{array}{l}\text {-It is all too easy to see information in terms of the equipment necessary } \\
\text { for its storage and transmission - I think people tend to concentrate on } \\
\text { what is more visible, more accessible, more easily quantifiable" (B) }\end{array}$ & & & $\checkmark$ & & & & & & & & & & & & & & & & & \\
\hline $\begin{array}{l}\text { - The information strategy is not like a mission statement - this is a } \\
\text { different order of generality - the strategy must specify not just the fit } \\
\text { between the area, the strategic area and the mission it must seek to go } \\
\text { one step further than that and indicate what are the key areas of activity } \\
\text { and quite specifically the responsible person, medium level of activity } \\
\text { and when actioned, plus date by which it is to be delivered and the } \\
\text { mechanism for reviewing" (B) }\end{array}$ & & & $\checkmark$ & & & & & & & & & & & & & & & & & \\
\hline $\begin{array}{l}\text { - "Previously I had responsibility for IT, I asked for an information strat- } \\
\text { egy and what came about was a technical document, it was this is what } \\
\text { we need to run the business, this is how we are going to get it" (E) }\end{array}$ & & & & & & $\checkmark$ & & & & & & & & & & & & & & \\
\hline $\begin{array}{l}\text {-What do people need to operate their departments? How are we going } \\
\text { to produce that - that's the' what'? Then the 'how' is the other thing we } \\
\text { have to be working on in the information strategy" (E) }\end{array}$ & & & & & & & $\checkmark$ & & & & & & & & & & & & & \\
\hline
\end{tabular}


- $\quad$ "There are two strands that I actually see - the information and the technology" (D)

- "Given the membership of the committee there is a general feeling they should know what an information strategy is - Yet it hasn't been made explicitly clear" (D)

- "I think that if you asked ten different people you will get ten different answers" (K)

- "I remember the first presentation, I must admit I didn't understand it in fact Thave it here in front of me and it still doesn't make a lot of sense to $\mathrm{me}$ " $(\mathrm{K})$

- $\quad$ "To me an information strategy should be something very simple, it should state that we have a firm belief that information should be free across the university" $(\mathrm{K})$

- $\quad$ "In the minutes of the last meeting particular issues were discussed about that I didn't think had anything to do with an information strategy but definitely with an IT strategy - there is a difference and whether everyone's perception is the same is not known" $(\mathrm{K})$

- "I think there was a feeling that the information strategy in the large respect was aligned to the technology" $(\mathrm{N})$

- Information is made available to all through the university's network $(\mathrm{N})$

- Often I find it difficult to find and access all of the information I require but the strategy will allow this to change (P)

\begin{tabular}{lll|l|l|l|l|l|l|l|l|l|l|l|l|l|l|l|l|l|l|} 
& & & & $\checkmark$ & & & & & & & & & & & & & \\
\hline
\end{tabular}




\section{Biography}

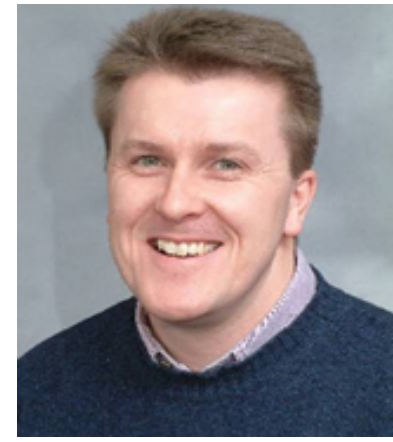

Karl Knox has for many years been involved with business issues from an information management perspective. His main research interests involve data, information and knowledge; information strategy and research methods all with a remit involving students and business issues. He has been on faculty at a variety of institutions within the UK, Middle East and Australia. He is currently a senior lecturer at Nottingham Business School. 